\title{
Impact of Remittances on Remittance-Recipient Households' Socio- Economic Behavior: A Study in Moulvibazar District of Bangladesh
}

\author{
Md. Abdul Hye \\ Lecturer, Department of History, Sunamganj Govt. College, Sunamganj, Bangladesh
}

\begin{abstract}
This study examines the socio-economic impacts of remittance on the remittance-recipient households through a primary survey in rural Bangladesh. We pay particular attention to the households who have received remittances for at least one year but not more than ten years. The size of remittances in Bangladesh is more than \$14 billion which is equivalent to about 11 percent of country's GDP. This large amount of remittance has helped shape Bangladesh's economy to a great extent for three decades. This socio-economic impact of remittances on remittance-recipient households is important in the sense that they continue to be a significant source of income for countless families and play a crucial role of co-insurance at times of hardship. The demonstration of relative economic solvency of remittance-recipient households encouraged encourage many more to migrate abroad for work which now has reached more than 9 million as of January 2015, as a consequence of high unemployment/underemployment rate in the country. From the results of the survey, it appears that higher duration of remittance-recipient households have higher level of income and investment, expenditure, and higher socioeconomic standing in the society.
\end{abstract}

Keywords- international migration, remittances, micro-level impact

\section{INTRODUCTION}

\subsection{Background}

Bangladesh has experienced a significant growth of migrant deployment and inflows of remittance in recent years. Bangladesh is a relatively labor abundant country and it participates in the supply side of the global labor market through supplying a large number of 'short-term migrants' ${ }^{1}$ worldwide. According to Bangladesh Manpower Employment and Training (BMET) (2015) data, the total number of Bangladeshi migrant workers increased from 6,087 in 1976 to 9.17 million in January, 2015 (Bangladesh Bank, 2015) ${ }^{2}$. Labor migration from Bangladesh increased rapidly since 2007, which put Bangladesh on a firm footing in remittance earning. Bangladesh has been ranked $8^{\text {th }}$ largest among remittance recipient nations grabbing a sizeable portion of remittances in 2013. The contribution of remittances equivalent to GDP of Bangladesh in 2013 was 12.2 percent (World Bank, 2014). Remittances play a crucial role in terms of foreign exchange earnings for Bangladesh and thus contribute directly to the country's national economy.

The social order in Bangladesh has long rested on kinship (Schendel, 2009, pp. 134,230) which helped Bangladesh in receiving remittances, as the migrants having strong ties with home tend to send a sizeable portion of income (remittance) back to Bangladesh (Islam, 2011). Remittances play an important role as the money sent from abroad directly reaches the household level and fairly densely distributed in the rural areas of Bangladesh, which is leading to positive changes at the micro level scenario of Bangladeshi society. Education, health, access to information and other socio-economic indicators are on the rise in areas receiving remittances. A recent Refugee and Migratory Movement Research Unit (RMMRU) study found that 'migration has an inverse relationship with poverty rate' (The Daily Star, Sep 1, 2014). So, migration through overseas employment has become an important livelihood

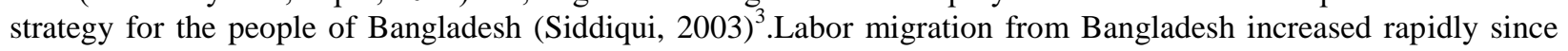

\footnotetext{
${ }^{1}$ Short-term represents the contractual migration especially for working purposes in which migrants cannot reside permanently, see Siddiqui (2003)

${ }^{2}$ See www.bangladesh-bank.org/econdata/wagermidtl.php

${ }^{3}$ RMMRU, Dhaka University, Bangladesh. Paper was presented at regional conference on 'Migration, Development and Pro-poor Policy Choices in Asia', held in Dhaka, on 22-24 June, 2003.
}

DOI: 10.9790/0837-2201054356 $\quad$ www.iosrjournals.org $\quad 43 \mid$ Page


Impact of Remittances on Households' Behavior

2007, which put Bangladesh on a firm footing in remittance earning. Most labors from Bangladesh work in Mid-east and Southeast Asian countries. Saudi Arabia, United Arab Emirates (UAE), Kuwait, Qatar, Oman, Iraq, Libya, Bahrain, Iran, Malaysia, South Korea, Singapore, Hong Kong and Brunei are some of the major countries of destination (Siddiqui, 2003, pp. 2-7), and remittances from these countries are increasing as more and more labors are seeking jobs in foreign markets. The main issue of this study is how remittances have been used in the livelihood of remittance-recipient households and how it impacts various socio-economic facets. The study area of Moulvibazar district is situated in the north-eastern part of Bangladesh, which is one of the largest migrant-sending districts of Bangladesh. Since, Moulvibazar district has become one of the largest remittance-recipient districts in the country and it constitutes $2.06 \%$ of total migrants of Bangladesh as of 2014 (BMET, 2015), it is important to evaluate the changing socio-economic dimensions of the district.

\subsection{Remittance: Theoretical Paradigm}

International remittance refers to money and goods that are transmitted to households back home by people working away from their origin communities (Adams, 1991) which indicates that remittances are household incomes received from abroad, resulting mainly from the international migration of workers (Yang, 2011, p. 129). According to Collins Cobuild Dictionary (2000), 'a remittance is a sum of money that you send to someone.' Recently, remittance has become a significant issue in world economy, especially for developing countries and gaining more prominence every day in research and policy debate on poverty alleviation and growth. The reason for heightened interest in monetary remittances is owing to a sharp rise in the amount transferred by migrants, mainly into developing countries. According to the World Bank (2014) ${ }^{4}$ estimation, remittances flows to the developing world would have reached USD 436 billion in 2014 (more than 8.4 per cent compared to 2013). The background of the 'regaining importance' of migration and remittances dates back to the dominating theory of dependency and structural ideas of 1970s and 1980s. Increasing remittance is considered a tool for achieving development goals, and thus 'developmentalist optimism' on remittances gets its firm footing in recent migration literature (Nepal Rastra Bank, 2012). In this theoretical background many developing and underdeveloped countries (such as Bangladesh) got involved in the process of migration (Papademetrion, 1985). Ratha (2013) considered remittances as the most tangible and least controversial link between migration and development.

\subsection{Remittances and the Change in Socio-economic Behavior}

Remittance is a part of the migrants' earnings sent back to home or the country of origin from the country of destination (Ahmed, 2012). The nexus between remittance and development remains complex, especially with regard to the movement of people, which contributes to the spread of global interdependence at all levels -social, economic and political (IOM, 2014). In the perspective of developing countries, remittances are largely part of riskmitigating strategies pursued by households and families (IOM, 2014). Remittances help to boost up the economy of developing countries in particular, and international organizations like International Labor Organization (ILO), International Organization for Migration (IOM), International Monetary Fund (IMF), World Bank and Asian Development Bank (ADB) are increasingly emphasizing migrants' remittance as a tool to promote development' (Siddiqui, 2004, pp. 7-11).

The links between international migration and remittances are 'self-evident' and considered as an important contributing factor towards economic development (Hass H. d., 2007). According to a study (World Bank, 2010) the amount of remittances is estimated to be three times the size of official development assistance (ODA) and provides an important lifeline to millions of poor households and a vital contribution to the national economy, mainly in two ways. First, migration reduces unemployment, and second, it increases the supply of foreign exchange which promotes business and investment, which in turn contribute to substantial economic gains both for remittance sending countries as well as receiving countries. Yet, until recently, the impact of migrants' remittances in socioeconomic development of recipient and sending countries was highly under-researched, mainly due to scarcity of data.

\subsection{Research Objective(s)}

The main objective of this study is to identify various socio-economic impacts of remittance on remittance-receiving households in Rajnagar upazila of Moulvibazar district. The study also aims to identify the use of remittance money

\footnotetext{
${ }^{4}$ The dataset for all countries is available at www.worldbank.org/migration. See the Migration and Development Brief, No 22, 11 April 2014.

${ }^{5}$ For details about the 'optimistic' and 'pessimistic views of remittances see Haas H. d. (2007).

DOI: 10.9790/0837-2201054356 $\quad$ www.iosrjournals.org $\quad 44 \mid$ Page
}


Impact of Remittances on Households' Behavior

for investment purposes. The specific objectives are to identify various impacts of remittances on remittancerecipient households' socio-economic conditions i.e. income and expenditure pattern, health, gender empowerment, information access etc.

\subsection{Data Gap and Limitations of the Study}

The study employs purposive sampling method which is the main drawback of the study, as the sample may not necessarily represent the population. Owing to time and resource constraints, the study was conducted only in Rajnagar upazila. Further, only three (3) unions are chosen out of total eight (8) unions in the upazila. The villages were chosen purposively, one from each union (assuming same characteristics, for administering the survey smoothly). Because of limited budget and time constraints, the study has taken into account of only few socioeconomic variables for analysis. The broader coverage of other impact areas may have been missed. Besides, the data collected from the sample households may not be fully accurate because respondents were generally reluctant to disclose the amount of remittances they receive and information regarding their end use. (IOM, 2014).

The study is based on recalling which inflicts further limitation on the study. For legitimizing the limitation, it is also assumed that there is no recall (memory) bias. As per this assumption, households were believed to be capable of remembering their household status when they had started receiving remittances, which may not be accurate for all households involved in the survey.

\section{LITERATURE REVIEW}

\subsection{Review of Existing Literature}

The impact of remittance on the migrant-sending households of Moulvibazar district has not been properly assessed as of now. On this rationale, this research was motivated to identify the impacts on various socio-economic dimensions of the households who are receiving remittances from abroad. The study includes a cross-section of socio-economic indicators to assess the impact comprising health, access to information, income and expenditure pattern and women empowerment. Bangladesh is one of the largest migrant sending countries in the world but the studies on migration and remittances are not so prolific. Some national, international, non-government organizations and few scholars in Bangladesh do conduct research on migration and remittances. International Organization for Migration (IOM), Bureau of Manpower Employment and Training (BMET), Refugee and Migratory Movement Research Unit (RMMRU), Bangladesh Bank (BB), Centre for Policy Dialogue (CPD) are some of the organizations who work on foreign migration and remittance related issues. Few such selected Bangladesh related literature reviews on remittances are cited below. Ahmed (2012) opined that migration and remittances could have mixed impact on migrant sending households. It helped households to sustain their livelihood and improve their living conditions. The study did not find any convincing proof regarding the impact of remittances on sustainable livelihood solution for migrant sending households. The findings of Ahmed give a general and qualitative analysis of the impact of remittance in a society which helps to understand the general pattern of remittances' impact.

The research wing of Bangladesh Bank (2011) conducted a comprehensive study on the uses of remittance money. The report demonstrated the existing scenario of remittance recipient households' socio-economic behavior by elaborating the pattern of their use of remittances. The study helps us to understand the existing scenario of the use of remittances though the change occurred through remittances in the micro-level cannot be understood from this study. It finds that 65 per cent of the households invest remittance money in education purposes which is regarded as a 'future investment' for country.

Jha et al. (2009) researched on 'Remittances and Household Welfare: A Case Study of Bangladesh' sponsored by Asian Development Bank (ADB) where impacts of remittances on household were shown but they did not include many key issues like education, health, etc. but rather an overall picture of impacts at the national level. The study finds upward trend in households' consumption level and the probability of a household becoming poor decreases by 5.9 per cent, if the household receives remittances. Islam (2012) emphasizes on the pattern and challenges of remittance flows where he also discusses the impacts of remittances on the household level as well. Apart from living conditions and housing, according to Islam (2012), migration promoted health and education level compared to pre-migration period in Bangladesh.Siddiqui (2004) tries to understand the existing use of remittances and the potentiality of productive investment of remittances for development. In this Asian Development Banks' initiative, Siddiqui emphasizes the use of remittances to understand the efficiency of migrant workers' remittances in Bangladesh perspective. The study finds remittance as an incentive to reduce poverty and it would be an important livelihood strategy of the poor.

Islam (2011), in his BMET paper tries to explore the pattern and socio-economic benefits of migration through which the contribution as well as impacts of remittances in the national economy of Bangladesh can be understood. 
Impact of Remittances on Households' Behavior

In his argument, reducing unemployment and injecting remittance money in the economy are the two ways through which migration helps shape the country's development process. This paper assessed the pattern of migration, socioeconomic benefit and impact of the remittances earned by expatriate workers. It has analyzed the use of remittance and contribution to the national economy of Bangladesh.BBS (2013) ${ }^{6}$ has conducted an important work to understand existing migration and remittance related aspects and it sought to shed light on the importance of the use of remittance as well as different other issues related to it. It is found in the study that remittances have led to improvements in the consumption of food among the majority of migrant households. Besides this, 20 per cent of migrant households receiving remittances reported their overall household incomes having increased because of remittances. Nepal Rashtra Bank (2012) of Nepal conducted a project namely "Impact Evaluation of Remittance: A Case Study of Dhanusha District" to identify the socio-economic change(s) owing to remittance earning. In this study they used Propensity Score Matching (PSM) approach to identify the socio-economic impacts of remittances at the household level. The study found the remittance-recipient households achieved better in various socioeconomic aspects in the society compared to non-recipient households.

Bhadra (2007) observed mixed impacts on the children of migrant mothers in Nepal. Positive impacts were detected on the opportunities of education, health care and lifestyle but worsening psychology of the children as their mothers stayed away for a long time..

Arif (2009) conducted a research on Pakistani Migrants living in Saudi Arabia to assess the impact on migrants' households living behind home. Arif found positive impact on the recipient-household on children's education, housing conditions, empowering women and overall social status of the family.

\subsection{Observation from Existing Literature}

The plethora of literature on remittance helps us understand that the importance of migration and remittances is increasing day by day. A large portion of literature articulated a national-level benefit of remittances poured into the developing economies. Besides this, the socio-economic impacts of remittance on household level are also discussed in some literature. As Bangladesh is one of the largest migrant sending countries in the world, works on remittance-related literature are building up rapidly. Most of the existing literature on remittance provides a positive view on remittance as the transfer of money from one country to another increase the national income of the recipient country and also reduces unemployment, especially in developing countries. Some literature also argued about the changes occurred in the society through increased remittance inflow reaching the household level.

\subsection{Research Gaps Identified from Literature Review}

The studies on the impact evaluation of remittances at the household level, for the case of Bangladesh, carried out so far have been limited, despite the fact that Bangladesh stands as one of the major remittance-recipient countries in the world. However, studies that have quantitatively examined the specific effects of remittances on education, health, financial access, women empowerment are small in number. Many existing literatures acquiesce the changing socio-economic pattern occurred by remittance receiving families living in home, but they do not conduct any extensive study on them. To our knowledge, no similar study of impact analysis on household's socioeconomic behavior has been carried out in Bangladesh which would identify the previous socio-economic conditions of the recipient family when they had not received remittances.

The reasons for this gap may well be a commonly held a priori supposition that a remittance receiving household would improve its poverty status, education level, access to information, etc. Thus, the contribution of this study will be to measure the extent of increasing expenditure, empowerment of women, more access to information and technology, higher education level, etc. induced by remittances if any, based upon the results.

\section{RESEARCH METHODOLOGY AND SURVEY DESIGN}

\subsection{Data Requirements}

Based on research objectives set out for the present study, it requires to have a good idea about the socioeconomic characteristics, uses of remittances and the pattern of behavioral changes by the sample households to unearth the impact of remittances on recipient families. Primary data from the household survey is the core of this study for achieving the objectives of understanding the socio-economic changes at the household level.

\subsection{Research Design and Methods}

The study was designed to conduct a primary survey in a pre and post-recall method. As there is no baseline data along with the inability to an experimental study, the research was designed to measure the impacts of

\footnotetext{
${ }^{6}$ Survey Report on the Use of Remittances 2013

DOI: 10.9790/0837-2201054356 $\quad$ www.iosrjournals.org $\quad 46 \mid$ Page
}


Impact of Remittances on Households' Behavior

remittances on remittance-recipient households based on pre and post recall by the respondent families. For understanding impacts of remittances, sample survey was conducted to understand various dimensions of socioeconomic characteristics of remittance-recipient households. Use of remittances can be an important element in determining the impact of remittances at the household level. As respondents or the sampling unit are sole remittance-recipient households, for understanding impacts on the recipient households, it was assumed that the duration of stay of migrants abroad could be one of the most important factors in determining the use of remittances by migrant families. A longer stay can provide families with more resources for investments (Arif, 2009) and thus, more conspicuous impact on the households' socio-economic behavior. The survey data are used to quantify the impacts on remittance-recipient households. For understanding the impact, households' remittance recipient period has been categorized into three parts such as: 1 year to 4 years, 5 years to 8 years, and 9 years to 10 years. The output from each category helps us to understand the changes occurred in the recipient family over time.

\subsubsection{Selection of Sample}

The sample of the study would be the remittance- recipient households who received remittances for at least one year but not more than ten years. It was assumed that at least one year was needed for a significant impact of remittances on recipient households. Furthermore, it has been assumed that migrants needed few months to settle in a foreign country and also the impact of remittances would be negligible during the early period of remittance receiving. The maximum period of ten years of remittance-receiving is deliberately chosen considering that the recall method would be comparatively less effective and the impact of remittances would be difficult to measure.

\subsubsection{Study Area}

The study area was selected considering the availability of families left behind by migrants. Since the sample population is scattered in a widely dispersed geographical area, some migration-prone pocket areas were purposively selected. Rural areas are considered the hub of reproducing migrants in the perspective of Bangladesh. Rajnagar upazila of Moulvibazar district has been chosen as the survey site considering that the region is one of the migrant-prone areas. The district is situated $211 \mathrm{~km}$ north-east from Dhaka. Rajnagar upazila is composed of eight union councils. The survey to collect data was conducted in three villages from three distinct union councils of Rajnagar upazilla of the district. The names of these three villages are Chelarchak, Ghargaon, Jauwa-Banarai which are from three distinct unions namely Uttarbagh, Rajnagar and Monsurnagar, respectively.

\subsubsection{Sampling Technique}

Households whose any member had been gainfully employed abroad for at least one year but not more than ten years were selected as the population of this survey. A purposive sampling was conducted in the absence of documentation and a database of the study population of Rajnagar upazila, as information about the recipient households is not updated and at times not even available in union council offices. The household information is also not updated since the last Household Income and Expenditure Survey (HIES) of Bangladesh Bureau of Statistics (BBS) was conducted in 2010. Under these circumstances, for collecting household information in the area, the author relied on 'Children and Literacy Survey 2009' data, available in local primary schools and by and large updated. From the above noted information, remittance-recipient households -who received remittances for at least one year but not more than ten years -were identified through a separate study/initiative with the help of the local union council members and the teachers of the respective primary schools. A list of 162 households -of whom Chelarchak village had 35 households, Ghargaon 80, and Jauwa-Banarai 47 -were identified.

\subsection{Collection of Data}

The tool of data collection in the survey was a semi-structured interview schedule for gathering information about the desired respondents. A survey questionnaire titled "Survey on Impact Evaluation" of Remittances 2015" was administered. The questionnaire was divided into six sections, ranging from household general socio-economic profile to household information on health, education, income, expenditure, information access, and women empowerment. The survey was carried out from $15^{\text {th }}$ January 2015 to $26^{\text {th }}$ January 2015 in the study area. The entire process of data collection was supervised by the author himself. Statistical Packages for Social Sciences (SPSS) software was used to process and analyze the collected data. 


\subsection{Characteristics of Households}

\section{DATA ANALYSIS}

Average Family member of the sample household is 6.3 where male average is 3.44 and female average is 2.86. Income from employment abroad is the main source of income in 94.7 per cent households among respondents.

\subsubsection{Household Type}

In this study, three types of homes of households are defined in the questionnaire of the survey, these are structure, semi-structure and hut (hay or tin shed roof). Overall, 55.3 per cent of household lived in structure dwellings and (Table 4.1) 32.5 per cent lived in semi-structure household. Only 12.3 per cent household lived in either thatched roofs or tin shed dwellings with walls made of bamboo, palm and/or mud.

\subsubsection{Water, Sanitation and Cooking}

Table 4.1 shows the distribution of migrants' households by their source of drinking water, type of cooking materials and toilet facilities they used. Access to improved source of water was about universal among the migrant households, because 96.5 per cent households used tube wells as the main source of drinking water. Pond water is used by only 3.5 per cent of households as the main source of drinking water. The table 4.1 shows most of the migrant households use sanitary latrine (91.2 per cent). Only 8.8 per cent households use non-sanitary latrine. All 114 households surveyed use firewood as the main fuel for cooking.

Table 4.1 General Characteristics of the Sample Households

\begin{tabular}{|c|c|c|c|}
\hline Characteristics & Type & Percentage & Frequency \\
\hline \multirow[t]{3}{*}{ 1. Household Type } & Structure & 55.3 & 63 \\
\hline & Semi-structure & 32.5 & 37 \\
\hline & Hut/Tin shed/Hay & 12.3 & 14 \\
\hline \multirow[t]{2}{*}{ 2. Source of Drinking Water } & Tube well & 96.5 & 110 \\
\hline & Pond & 3.5 & 4 \\
\hline \multirow[t]{2}{*}{ 3. Toilet Type } & Sanitary Latrine & 91.1 & 104 \\
\hline & $\begin{array}{c}\text { Non-sanitary } \\
\text { Latrine }\end{array}$ & 8.8 & 10 \\
\hline \multirow{2}{*}{ 4. Family Type } & I & 561 & 64 \\
\hline & Nuclear & 43.9 & 50 \\
\hline \multirow{3}{*}{ 5. Source of Light } & Electricity & 85.1 & 97 \\
\hline & Solar Energy & 7.0 & 8 \\
\hline & Kerosene & 7.9 & 9 \\
\hline \multirow[t]{6}{*}{ 6. Possession of Selected Assets } & Television & 99.1 & 113 \\
\hline & Cell Phone & 100 & 114 \\
\hline & Telephone & 0 & 0 \\
\hline & DVD/VCD & 23.7 & 27 \\
\hline & Laptop/Computer & 7.9 & 9 \\
\hline & $\begin{array}{l}\text { Motorcycle/CNG } \\
\text { Scooter }\end{array}$ & 20.2 & 23 \\
\hline \multirow{3}{*}{$\begin{array}{c}\text { 7. Possession of Agricultural land/ } \\
\text { Business }\end{array}$} & Agricultural Land & 84.2 & 96 \\
\hline & Cattle & 49.1 & 56 \\
\hline & $\begin{array}{l}\text { Business (small / } \\
\text { medium) }\end{array}$ & 18.4 & 21 \\
\hline
\end{tabular}

Source: Author's own calculation from the survey, 2015 


\subsubsection{Family Type}

Joint family arrangement sustains still among migrant households as 56.1 per cent (64) households live in joint families. About 43.9 per cent (50) households live in nuclear family. (Table 4.1)

\subsubsection{Source of Light /Power}

Table 4.1 shows that among the sampled 114 migrant households, 97 (85.1per cent) households have had access to electricity. Solar energy ( 7.0 per cent) and kerosene ( 7.9 per cent) are also used by some households.

\subsubsection{Possession of Selected Durable Goods}

Table 4.1 gives a breakdown of selected possessions owned by migrant households. Overall, 99.1 per cent (113) household owned television, 23.7 per cent (27) a DVD or VCD, 7.9 per cent (9) had laptop or computer, 20.2 per cent (23) owned motorcycle or CNG scooter. All the households have had cell phone but no household had access to land-telephone service.

\subsubsection{Possession of Agricultural Land and Business}

Table 4.1 represents overall 84.2 per cent of migrant households owned agricultural land. Almost fifty per cent (49.1 per cent) possess domestic animals and $18.4 \%$ households owned at least a small or medium size business.

\subsubsection{Amount of Cultivable Land Possessed}

Table 4.2 shows the amount of cultivable land possessed by migrant households. Among the sampled migrant households, 15.8 per cent (18) have no cultivable land at all and about one-third (32.5 per cent) have owned less than a bigha ${ }^{7}$ of cultivable land. On average, thirty seven per cent of the total migrant households have five to ten bighas of cultivable land.

Table 4.2 Possession of Cultivable Land

\begin{tabular}{|l|l|l|}
\hline Cultivable Land (in Bigha) & Frequency & Percentage \\
\hline No Cultivable Land & 18 & 15.8 \\
\hline$<5$ & 37 & 32.5 \\
\hline $5-10$ & 43 & 37.6 \\
\hline $11-20$ & 10 & 8.9 \\
\hline$>20$ & 6 & 5.3 \\
\hline Total & 114 & 100 \\
\hline
\end{tabular}

Source: Author's own calculation from the survey, 2015

Approximately nine per cent of the households have eleven to twenty bighas of cultivable land.

\subsection{Characteristics of Migration and Migrants}

4.2.1 Sex and Marital Status of Migrants

Table 4.3: Marital Status

\begin{tabular}{|l|l|l|}
\hline Marital Status & Frequency & Percentage \\
\hline Single & 91 & 79.82 \\
\hline Married & 23 & 20.18 \\
\hline Total & 114 & 100 \\
\hline
\end{tabular}

Source: Author's own calculation from the survey, 2015

All the migrants of the sampled households are male. Four to five $(79.82 \%)$ migrants are married during the time of survey while 20.18 per cent of them were not married yet.

4.2.2 Education

Most migrants have little education. In Table 4.2, approximately seventy per cent of migrants have education below secondary school certificate. Six percent have no education at all, fifty per cent have only primary education from grade one to five, and however, 13.2 per cent have education from grade six to nine. About 17.5 per cent migrants have education level from grade 10 to secondary school certificate (SSC) and seven per cent migrants fall into grade 11 to higher secondary school certificate (HSC) i.e. grade 12. Only 6.2 per cent of migrants completed their graduation and above.

${ }^{7}$ One bigha equals approximately 0.33 acre.

\begin{tabular}{lll}
\hline DOI: $10.9790 / 0837-2201054356$ & www.iosrjournals.org & $49 \mid$ Page
\end{tabular}


Table 4.4: Level of Education

\begin{tabular}{|l|l|l|}
\hline Level of Education & Frequency & Percentage \\
\hline $\begin{array}{l}\text { Post Graduate (post } \\
\text { baccalaureate) }\end{array}$ & 2 & 1.8 \\
\hline Graduate (baccalaureate) & 5 & 4.4 \\
\hline Class 11-HSC & 8 & 7 \\
\hline Class 10-SSC & 20 & 17.5 \\
\hline Class 6-Class 9 & 15 & 13.2 \\
\hline Class 1-Class 5 & $\mathbf{5 7}$ & $\mathbf{5 0}$ \\
\hline Illiterate & 7 & 6.1 \\
\hline Total & 114 & 100 \\
\hline
\end{tabular}

Source: Author's own calculation from the survey, 2015

4.2.3 Migrants' Country of Destinations

From 4.3 shows, the main destination of migrants is the countries of Middle East. Kingdom of Saudi Arabia (KSA) is in the top where 40.35 per cent of the migrants resided during the time of survey. United Arab Emirates (UAE)

Table 4.5: Migrants' Country of Destinations

\begin{tabular}{|l|l|l|}
\hline Country & Frequency & Percentage \\
\hline Bahrain & 3 & 2.63 \\
\hline Denmark & 1 & 0.88 \\
\hline KSA & 46 & 40.35 \\
\hline Oman & 8 & 7.02 \\
\hline Qatar & 23 & 20.18 \\
\hline S. Africa & 1 & 0.88 \\
\hline UAE & 26 & 22.81 \\
\hline UK & 4 & 3.51 \\
\hline USA & 2 & 1.75 \\
\hline Total & 114 & 100 \\
\hline
\end{tabular}

Source: Author's own calculation from the survey, 2015

and Qatar with 22.81 per cent and 20.18 per cent respectively stand out next as the destination of migrants. Oman (7.02 per cent) is also a significant country of migrants' destination. United Kingdom (UK), United States of America (USA) and Bahrain constitute 3.51, 1.75 and 2.63 per cent of migrants' destination countries respectively.

\subsubsection{Expenses Related to Migration}

The price of migration varies by a wide range. On average the migration expenses per migrant are BDT 2,10000. About 12.3 per cent (14) migration spent below one lac ${ }^{8}$ and fifty thousand for the sake of migration. Approximately, 30.7 per cent migrants paid one lac fifty thousand to below three lacs. However, half of the migrants spent two to below three lacs. Only in seven instances (6.1 per cent) migration cost exceeded three lacs.

Table 4.6: Expenses Related to Migration

\begin{tabular}{|l|l|l|}
\hline Cost (in lac) (in $B D T)$ & Frequency & Percentage \\
\hline Below 1.50 lac & 14 & 12.3 \\
\hline 1.5 lac to 1.99 lac & 35 & 30.7 \\
\hline 2.0 lac to 2.99 lac & 58 & 50.9 \\
\hline 3.0 lac and above & 7 & 6.1 \\
\hline
\end{tabular}

Source: Author's own calculation from the survey, 2015

\footnotetext{
${ }^{8}$ One 'lac' equals one hundred thousand

DOI: $10.9790 / 0837-2201054356 \quad$ www.iosrjournals.org $50 \mid$ Page
} 
4.2.5 Finance of Migration Expenditure

The expenses of migration are financed by different sources. The table 4.7 shows, the main sources which financed major portion of migration expenditure are selling or mortgaging land and borrowing from relatives. Approximately, 39.5 per cent households financed expenses of migration by selling or mortgaging land. Borrowing from relatives where no interest payment is required was done by 39.5 per cent migrants. Borrowing on interest financed a sizeable portion, 10.5 per cent of migrants. Seven per cent households financed migration expenditure from money saved with financial institutions. Only a small portion ( 3.5 per cent) financed the migration expenditure by selling jewelry.

Table 4.7: Finance of Migration Expenses

\begin{tabular}{|l|l|l|}
\hline Source of Finance & Frequency & Percentage \\
\hline Selling or Mortgaging Land & 45 & 39.5 \\
\hline Selling Jewelry & 4 & 3.5 \\
\hline Debt (with interest) & 12 & 10.5 \\
\hline $\begin{array}{l}\text { Debt from Relatives (without } \\
\text { interest) }\end{array}$ & 45 & 39.5 \\
\hline Others(Money savings in FI) & 8 & 7 \\
\hline Total & 114 & 100 \\
\hline
\end{tabular}

Source: Author's own calculation from the survey, 2015

\subsection{Receipt of Remittances: Before and After}

\subsubsection{Family Type}

In the Table 4.5, it is shown that the tradition of joint family living is decreasing among remittance-recipient households. Before remittance receiving 94.74 per cent households were living in joint family which declined to 56.1 per cent at present. Thus, living in nuclear family has increased to 43.9 per cent from a mere 5.26 per cent.

Table 4.8: Family type of the Respondents

\begin{tabular}{|l|l|l|}
\hline Family Type & Before receiving remittances & At Present \\
\hline Joint & $94.74(108)$ & $56.1(64)$ \\
\hline Nuclear & $5.26(6)$ & $43.9(50)$ \\
\hline Total & $100(114)$ & $100(114)$ \\
\hline
\end{tabular}

Source: Author's own calculation from the survey, 2015

\subsubsection{House Type}

Table 4.9: House Type of the Respondents

\begin{tabular}{|l|l|l|}
\hline House Type & Before receiving remittances & At Present \\
\hline Hut & $76.3(87)$ & $12.3(14)$ \\
\hline Semi-structure & $21.9(25)$ & $32.5(37)$ \\
\hline Structure & $1.8(2)$ & $55.3(63)$ \\
\hline Total & $100(114)$ & $100(114)$ \\
\hline
\end{tabular}

Source: Author's own calculation from the survey, 2015

Table 4.9 shows the number of structure has proliferated from only 1.8 percent to 55.3 per cent. While 76.3 per cent households were hut (hay or tin shed roof with bamboo or tin made side walls) before receiving remittances, now it has come down only 12.3 per cent. The Table also represents that semi-structure houses also increased to 32.5 percent from 21.9 per cent.

\subsubsection{Toilet Type}

Before receiving remittances only 21.9 per cent households used sanitary latrine which rose to 91.2 per cent at the time of survey. (Table 4.10). Though a sizeable portion of households use non-sanitary latrine before receiving remittances, at present only 8.8 per cent households do so. Few ( 3.5 per cent) had no toilet facilities at all before receiving remittances, but now every household has toilet facilities. 
Impact of Remittances on Households' Behavior

Table 4.10: Toilet Type

\begin{tabular}{|l|l|l|}
\hline Toilet Type & $\begin{array}{l}\text { Before receiving } \\
\text { remittances }\end{array}$ & At Present \\
\hline Sanitary & $21.9(25)$ & $91.2(104)$ \\
\hline Non-sanitary & $74.6(85)$ & $8.8(10)$ \\
\hline No Toilet & $3.5(4)$ & $0(0)$ \\
\hline Total & $100(114)$ & $100(114)$ \\
\hline
\end{tabular}

Source: Author's own calculation from the survey, 2015

\subsection{Impact of Remittances}

For understanding the impacts of remittances on the recipient households, the duration of receiving remittances are partitioned into three parts of one to four years, five to eight years and nine to ten years. Among 114 remittancerecipient households 29 (25.4 per cent) households received remittances for four years, 46 (40.4 per cent) households received from five to eight years and 39 (34.2 per cent) households for nine or ten years.

Table 4.11: Segmentation of Sample Household

\begin{tabular}{|c|c|c|}
\hline Partitioned Segments & Frequency & Percentage \\
\hline 1 to 4 years & 29 & 25.4 \\
\hline 5 to 8 years & 46 & 40.4 \\
\hline 9 to 10 years & 39 & 34.2 \\
\hline Total & 114 & 100 \\
\hline
\end{tabular}

Source: Author's own calculation from the survey, 2015

4.4.1 Households' Financial Decision

Table 4.12 shows the decision pattern of family's financial transaction. About 35.1 per cent of households decisions on financial transactions were taken by male compared to only 17.5 per cent by female. Forty seven per cent households take their financial decision jointly.

Table 4.12: Decision Regarding Households’ Financial Transaction

\begin{tabular}{|l|l|l|l|l|}
\hline Decision By & $\begin{array}{l}\text { Received for 01-04 } \\
\text { years }\end{array}$ & $\begin{array}{l}\text { Received for 05-08 } \\
\text { years }\end{array}$ & $\begin{array}{l}\text { Received for } \\
\text { 09-10 years }\end{array}$ & $\begin{array}{l}\text { On Average (\% } \\
\text { of all } \\
\text { respondents }\end{array}$ \\
\hline Male & $51.7(15)$ & $30.4(14)$ & $28.2(11)$ & $35.1(40)$ \\
\hline Female & $17.2(5)$ & $17.4(8)$ & $17.9(7)$ & $17.5(20)$ \\
\hline Jointly & $31(9)$ & $52.2(24)$ & $53.8(21)$ & $47.4(54)$ \\
\hline Total & $100(29)$ & $100(46)$ & $100(39)$ & $100(114)$ \\
\hline
\end{tabular}

Source: Author's own calculation from the survey, 2015

Male's participation in decision making regarding households' financial transaction is decreasing as they were abroad and could not be actively involved from outside. The portion of male's decision among who receive remittances from one to four years is 51.7 per cent which has decreased to 28.2 per cent for those who receive remittances for nine to ten years.

\subsubsection{Female's Permission to Go Outside}

Table 4.13 posits the graphical representation of female's permission to go outside of the households. In about 56.1 per cent households, female need to inform male members while going outside of the house. In 12.3 per cent households women do not need to take permission of other male member(s) of the household. The percentage of permission dependency of female members is decreasing over time as 37.9 per cent (who receive remittances for one to four years) has eroded to 17.9 per cent only for those who have been receiving remittances for nine to ten years. As a consequence the percentage of households who 'need not to inform' has been increasing over time as can be seen in the graph. 
Impact of Remittances on Households' Behavior

Table 4.13: Female's Permission to Go Outside

\begin{tabular}{|c|c|c|c|c|}
\hline Permission Type & $\begin{array}{l}\text { Received for } \\
01-04 \text { years }\end{array}$ & $\begin{array}{l}\text { Received for } \\
05-08 \text { years }\end{array}$ & $\begin{array}{l}\text { Received for } \\
09-10 \text { years }\end{array}$ & $\begin{array}{l}\text { On Average } \\
\text { (\% of all } \\
\text { respondents) }\end{array}$ \\
\hline Need to take & $37.9(11)$ & $19.6(9)$ & $17.9(7)$ & $23.7(27)$ \\
\hline Need not to take & $3.4(1)$ & $13(6)$ & $5.1(2)$ & $7.9(9)$ \\
\hline Need to inform & $51.7(15)$ & $56.5(26)$ & $59(23)$ & $56.1(64)$ \\
\hline $\begin{array}{l}\text { Need not to } \\
\text { inform }\end{array}$ & $6.9(2)$ & $10.9(5)$ & $17.9(7)$ & $12.3(14)$ \\
\hline Total & $100(29)$ & $100(46)$ & $100(39)$ & $100(114)$ \\
\hline
\end{tabular}

Source: Author's own calculation from the survey, 2015

\subsubsection{Place of Health Services}

Table 4.14 shows that 67.5 per cent households use government hospital while 32.5 per cent household use private clinic for health services. The use of private clinic is more frequent among the households who receive remittances for longer period. Approximately 20.7 per cent of households who receive remittances for one to four years use private clinic, which is increased to 46.2 per cent among those households who receive remittances for nine to ten years.

Table 4.14: Place of Health Services Used by Households $\quad$ (\% in households)

\begin{tabular}{|l|l|l|l|l|}
\hline Service Place & $\begin{array}{l}\text { Received for 01- } \\
\text { 04 years }\end{array}$ & $\begin{array}{l}\text { Received for 05- } \\
\text { 08 years }\end{array}$ & $\begin{array}{l}\text { Received for } \\
\text { 09-10 years }\end{array}$ & $\begin{array}{l}\text { On Average (\% of } \\
\text { all respondents) }\end{array}$ \\
\hline Govt. Hospital & $79.3(23)$ & $71.7(33)$ & $53.8(21)$ & $67.5(77)$ \\
\hline Private Clinic & $20.7(6)$ & $28.3(13)$ & $46.2(18)$ & $32.5(37)$ \\
\hline Total & $100(29)$ & $100(46)$ & $100(39)$ & $100(114)$ \\
\hline
\end{tabular}

Source: Author's own calculation from the survey, 2015

\subsubsection{Households' Internet Use}

Among respondents, on average 57 per cent households use internet. The portion using internet is higher among households who receive remittances for a longer period. Only 34.5 per cent households use internet who are receiving remittances for one to four years but it increased to 74.4 per cent among households who received remittances for nine to ten years.

Table 4.15: Rate of Change of Internet Use Over Time (\% in households)

\begin{tabular}{|l|l|l|}
\hline $\begin{array}{l}\text { Period of receiving } \\
\text { remittances }\end{array}$ & Frequency & Percentage \\
\hline $1-4$ years & 10 & 34.5 \\
\hline $5-8$ years & 26 & 56.5 \\
\hline 9-10 years & 29 & 74.4 \\
\hline On Average & 65 & 57 \\
\hline
\end{tabular}

Source: Author's own calculation from the survey, 2015

\subsubsection{Households' Using Remittances for Business Purposes}

Table 4.16 elaborates the portion of households who invest remittance money for business purposes. Only 11.4 per cent households invest in business purposes. Percentage of households who invest remittances in business purposes is higher among the longer period remittance recipient households. While 15.4 percent of households who receive remittances for nine to ten years invest remittances for business purposes, the portion is only 3.4 per cent who receive remittances for one to four years.

Table 4.16: Households Using Remittances in Business Purposes (\% in households)

\begin{tabular}{|l|l|l|}
\hline $\begin{array}{l}\text { Period of receiving } \\
\text { remittances }\end{array}$ & Frequency & Percentage \\
\hline $1-4$ years & 1 & 3.4 \\
\hline $5-8$ years & 6 & 13 \\
\hline
\end{tabular}


Impact of Remittances on Households' Behavior

\begin{tabular}{|l|l|l|}
\hline 9-10 years & 6 & 15.4 \\
\hline On Average & 13 & 11.4 \\
\hline
\end{tabular}

Source: Author's own calculation from the survey, 2015

\subsubsection{Households' Using Remittance Money for Buying Lands}

Table 4.17 shows the portion of households using remittance money for buying lands. About 59.6 per cent households use remittances for land purchase. The households' percentage using remittances for buying lands is higher who have been receiving remittances for longer period. While 79.5 per cent of households who have received remittances for nine to ten years spend remittance money for purchasing lands, the portion is only 31 per cent receiving remittances for one to four years.

Table 4.17: Household Using Remittances for Buying Lands (\% in households)

\begin{tabular}{|l|l|l|}
\hline $\begin{array}{l}\text { Period of receiving } \\
\text { remittances }\end{array}$ & Frequency & Percentage \\
\hline $1-4$ years & 9 & 31.0 \\
\hline 5-8 years & 28 & 60.9 \\
\hline 9-10 years & 31 & 79.5 \\
\hline $\begin{array}{l}\text { On Average (\% of all } \\
\text { respondents) }\end{array}$ & 68 & 59.6 \\
\hline
\end{tabular}

Source: Author's own calculation from the survey, 2015

\subsubsection{Expenditure Pattern}

Table 4.18 shows monthly expenditure pattern of respondent households where 57 per cent household have monthly expenditure of BDT 10001 to BDT 20000, 18.4 per cent have less than BDT 10000 and 16.7 per cent BDT 20001 to BDT 30000. Only 7.9 per cent have monthly expenditure of more than BDT 30000. The households who receive remittances for longer period have higher expenditure. Only 3.4 per cent households have monthly expenditure of BDT 30001 and above who have been receiving remittances for one to four years but the percentage rose to 10.3 for those who receive remittances for nine to ten years.

Table 4.18: Households' Expenditure Per Month (in BDT)

\begin{tabular}{|l|l|l|l|l|}
\hline $\begin{array}{l}\text { Expenditure on } \\
\text { Education }\end{array}$ & $\begin{array}{l}\text { Received for 01- } \\
\text { 04 years }\end{array}$ & $\begin{array}{l}\text { Received for 05- } \\
\text { 08 years }\end{array}$ & $\begin{array}{l}\text { Received for 09- } \\
10 \text { years }\end{array}$ & $\begin{array}{l}\text { On Average (\% } \\
\text { of respondents }\end{array}$ \\
\hline 0 to 10000 & $20.7(6)$ & $19.6(9)$ & $15.4(6)$ & $18.4(21)$ \\
\hline 10001 to 20000 & $62.1(18)$ & $56.5(260$ & $53.8(21)$ & $57(65)$ \\
\hline $20001-30000$ & $13.8(4)$ & $15.2(7)$ & $20.5(8)$ & $16.7(19)$ \\
\hline 30001 and above & $3.4(1)$ & $8.7(7)$ & $10.3(4)$ & $7.9(19)$ \\
\hline Total & $\mathbf{1 0 0}$ & $\mathbf{1 0 0}$ & $\mathbf{1 0 0}$ & $\mathbf{1 0 0}$ \\
\hline
\end{tabular}

Source: Author's own calculation from the survey, 2015

\section{SUMMARY AND CONCLUSION}

\subsection{Major Findings of the Study}

Remittance income is emerging as one of the most significant and reliable sources of external finances for many developing countries. Not only at the macro level, the contribution of remittances has been direct and sizable to migrant-sending households at the micro level as well. A significant number of people in developing world are now receiving remittance income to finance their expenditures in home consumption, health and in information technology. The main objective of the study was to identify various socio-economic impacts of remittances on recipient households. Receiving remittances is presumed to have some effects on various socio-economic issues.

$>$ Percentage of joint family is 94.76 per cent before receiving remittances which has dwindled to 56.1 per cent following the receipts of remittance income.

$>$ Before receiving remittances only 1.8 per cent houses were of structure type which has increased to 55.3 per cent during the time of the survey. Remittance money might have played important role for leading to this dramatic change.

$>$ Only 21.9 per cent households used sanitary latrine before receiving remittances but now it is about 91.2 per cent using sanitary latrine, thanks to remittances which might have played a vital role in bringing about the change. 
Through evaluating remittance-recipient households only, it is difficult to measure impact as there are no data of non-recipient households to compare with. The study employs, for impact analysis, through partitioning the duration of receiving remittances into three and then compares the findings to evaluate the effect of remittance income on various socio-economic dimensions of migrant households.

$>$ Only $11.4 \%$ households invested remittances in business activities. Among the households who received remittances for one to four years, only 3.4 per cent households invested remittances in business, the percentage is 15.4 among the households who received remittances for nine to ten years.

$>$ Longer period (9 to 10 years) remittance recipient households use more private clinic than that of government hospitals. About 46.2 per cent of nine to ten years remittance-recipient households use private clinics, whereas the portion is only 20.7 per cent who receive remittance for one to four years.

$>$ Longer period (9 to 10 years) remittance recipient households are more likely to using internet, as 74.4 per cent households use internet while only 34.5 per cent among the households who receive remittances for one to four years, use internet.

$>$ Women decision making role is more prominent (higher percentage) among the longer period remittance recipient households. Male percentage in taking financial decisions in family is reduced from 51.7 per cent (among 1 to 4 years remittance-recipient households) to 28.1 per cent (among 9 to 10 years recipient households).

$>$ The households who receive remittances for longer period (nine to ten years) have higher expenditure ratio (e.g. BDT 30000 and above) compare to less period of remittance-recipient households.

\subsection{RECOMMENDATIONS}

Based on the analysis above, the following recommendations are forwarded for consideration of policy-makers and others concerned:

$>$ The expenditure pattern of remittance recipient households indicates that remittance earnings are mostly being used in non-productive areas such as in erecting luxurious houses and conspicuous consumption, and as such no significant impact of remittance on productive investment. This trend needs immediate change through developing appropriate policy measures so as to encourage remittance-recipient households to use their money in productive areas e.g. invest in manufacturing. Investment in Bangladesh is complicated because of bureaucratic snags and political instability which work as serious impediment to investment, and this needs to be addressed by authorities. As microfinance institutions have deeper penetration in rural areas, Bangladesh can consider utilizing these institutions to mobilize remittance earning in poverty-stricken areas.

$>$ The study reveals that half of the migrants' level of education ranges from grade 1 to grade 5 which indicates that most of the migrants' education level is low. As it is appears that remittances have positive impact on society, concerned authorities can take necessary arrangements to produce skilled and trained labor e.g. nurse, carpenter, meson, driver, and electrician etc., especially from among low earning segments of the population of the society. By sending abroad, the skilled labor would have easier access to professional labor market abroad. This certainly would have a stronger positive impact on the amount of remittance inflow, which will have a greater contribution towards country's economic development through enhancement of the availability of foreign exchange reserve.

\section{REFERENCES}

[1] Adams, R. H. (1991). The Economic Uses and Impact of International Remittances in Rural Egypt. Economic Development and Cultural Change, 594-722.

[2] Ahmad, Q. K., \& Fatema, Z. (1997). Utilization of Remittances from Abroad for Local Employment Promotion - The Case of Sylhet Division. Dhaka: International Labor organization (ILO), Bangladesh Unnayan Parishad (BUP).

[3] Ahmed, S. M. (2012). Migration Remittance and Household Development. Lund: Lund University Master of International Development and Management.

[4] Arif, G. M. (2009). Economic and Social Impacts of Remittances on Households: A Case Study of Pakistani Migrants working in Saudi Arabia. Geneva: International Organization for Migration (IOM).

[5] Bangladesh Bank. (2015). Retrieved February 12, 2015, from Bangladesh Bank Web site: www.bangladesh-bank.org

[6] Bangladesh Bank. (2011). The Use of Remittances in Bangladesh: Future Prospects (in Bengali). Dhaka: Research Wing, Bangladesh Bank.

[7] Bangladesh Bank. (2011). Use of Remittance in Bangladesh (in Bangla). Dhaka: Research Wing, Bangladesh Bank.

[8] BBS. (2013). Survey Report on the Use of Remittances. Dhaka: Bangladesh Bureau of Statistics (BBS).

[9] Bhadra, C. (2007). International Labour Migration Of Nepalese Women: The Impact Of Their Remittances On Poverty Reduction . AsiaPacific Research and Training Network on Trade Working Paper Series, No 44.

[10] BMET. (2015). Bangladesh Bureau of Manpower, Employment \& Training (BMET). Retrieved from Bangladesh Bureau of Manpower, Employment \& Training web site: www.bmet.gov.bd

[11] Collins Cobuild Dictionary. (2000). London: HarperCollins Publishers. 
[12] Haas, H. d. (2007). Remittances, Migration and Social Development A Conceptual Review of the Literature. Geneva: This United Nations Research Institute for Social Development (UNRISD).

[13] IOM. (2014). The Impact of Remittances on Developing Countries. Hague: Directorate-General For External Policies of The Union, Directorate B.

[14] Islam. (2012). Policy and Program on Overseas Employment and flow of Remittance: Issues and challenges. Dhaka: IMRO.

[15] Islam, N. (2011). Bangladesh ExpatriateWorkers and their Contribution to National Development. Dhaka: Bangladeh Manpower Employment and Training.

[16] NRB. (2012). Impact Evaluation of Remittances: A Case Study of Dhanusha District. Janakpur, Nepal: Banking Development and Research Unit, Nepal Rastra Bank.

[17] Papademetrion, D. G. (1985). Illusions and reality in international migration: Migration and development in post world war2 Greece. International Migration, 211-223.

[18] Raihan, S., Khondker, B. H., Sugiyarto, G., \& and Jha, S. (2009). Remittances and Household Welfare: A Case Study of Bangladesh. Manila: Asian Development bank.

[19] Ratha, D. (2013). The Impact of Remittances on Economic Growth and Poverty Reduction. Washington DC: Migration Policy Institute.

[20] Schendel, W. V. (2009). A History of Bangladesh. New Delhi: Cambride University Press.

[21] Siddiqui. (2004). Efficiency of Migrant Workers' Remittance: The Bangladesh Case. Manila: Asian Development Bank.

[22] Siddiqui, T. (2003). Migration As A Livelihood Strategy Of The Poor: The Bangladesh Case. University of Dhaka. Dhaka: Refugee and Migratory Movements Research Unit (RMMRU).

[23] World Bank. (2010). Retrieved from World Bank Web site: /INTPROSPECTS/Resources/334934-1199807908806/World.pdf

[24] WorldBank.(2013RetrievedfromWorldBankwebsite:

WBSITE/EXTERNAL/TOPICS/0,,contentMDK:21924020 pagePK:5105988 piPK:360975 theSitePK:214971,00.html

[25] World Bank. (2015). Retrieved 2015, from World Bank Web site: www.worldbank.orgYang, D. (2011). Migrant Remittances. Journal of Economic Perspectives , 25 (3), 129-152 